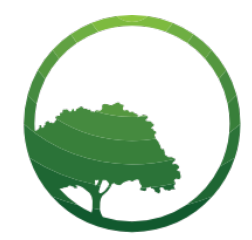

Business \& Social Science IJRBS

\section{Research in Business and Social Science}

IJRBS Vol 6 No 5, Special Issue, ISSN: 2147-4478

Contents available at www.ssbfnet.com/ojs

http://dx.doi.org/10.20525/ijrbs.v6i5.762

\title{
Study towards Sustainable Performance Improvement Based on Organizational Citizenship Behavior in People Credit Board (BPR) East Java Indonesia
}

\section{Sri Harnani}

Institute of Economic Science of Jaya Negara Malang, Indonesia 0341-491154

\section{Abstract}

This research aims to apply different variables with previous research variables, i.e., organization behavior theory development. Testing Organizational Citizenship Behavior (OCB) variable in mediating transformational leadership and working satisfaction to improve People Credit Board's (BPR) performance. This research is conducted to 319 BPR employers in credit section in East Java. Samples amount calculated based on Slovin's equation therefore it acquired 76 respondents. Sampling method used simple random sampling. Data taking instrument is questionnaire which next can be used path analysis in processing data. This research result shows that there significant influence of transformational leadership and working satisfaction towards OCB and OCB mediates transformational leadership and working satisfaction towards performance. It means that OCB will increase with the increasing transformational leadership and working satisfaction. Next, OCB increased due to the increase in transformational leadership and working satisfaction that tend to improve performance.

Keywords: Transformational Leadership, Working Satisfaction, Organizational Citizenship Behavior, Performance, People Credit Bank

JEL: D22, D910, G410

\section{Introduction}

Performance of working achievement is the result achieved by employees based on the set criteria. As one of banking business forms, the success of People Credit Bank (BPR) in East Java is influenced by leadership concept applied and working satisfaction concept so it grows employees Organizational Citizenship Behavior (OCB). Employees OCB is important factor in improving employees' performance. This Organizational Citizenship Behavior (OCB) is extra role behavior not directly related to reward system in prioritizing organization's interest, OCB is any 


\section{S. Harnani / International Journal of Research in Business and Social Science, Vol 6 No 5, Special Issue 2017 ISSN: 2147-4486}

positive behavior outside an employee's official job requirements that contributes to the wellbeing of the organization (Lyons \& Schneider, 2005).

BPR is financial institution founded to serve the communities in villages and suburban areas, including Medium, Small, and Micro business (UMKM) owners (Njotoprajitno, 2012). According to Siamat (2005: 399), BPR functions to provide banking service to communities, to educate and to build understanding of development acceleration pattern in village sector, to create business opportunity equity for villagers and to accelerate communities' understanding towards the utilization of formal financial institution. BPR business activities consisted of providing funding based on profit sharing and allocating it's fund in the form of Bank of Indonesia Certificate (SBI), deposit, and or savings in other banks (Siamat, 2005: 59). BPR is expected to be working partner for UMKM-the business and company type which is highest number among businesses in Indonesia.

Various problems faced by BPR in serving and developing UMKM, i.e., limited service range, small business scale, the continuously rising competition, technological and capital problem. The majority of BPR customers are UMKM which still need competitiveness improvement. Internal problem is the quantity and quality limitation of human resource in monitoring credit disbursed. Credit disbursement risk to customers is the delays in fund return or even funds ended up unreturned due to customers' failure in returning the credit in time. The credit ended up became Non Performing Loans (NPL).

NPL in BPR in East Java ended up became BPR performance measurement value formed from employees' performance, especially employees in credit section. Tolerable is $5 \%$ at maximum (malangvoice,com, November 2 2016). BPR has NPL ratios exceeding 5\%, and therefore must be comprehensively evaluated in order to make general BPR operations uninterrupted.

Previous research conducted by Zeinabadi (2010) that took teachers in Tehran as respondents with the result shows that intrinsic job satisfaction has significant direct effect on Organizational Citizenship Behavior (OCB). Next, Chiang and Hsieh (2012) found positive influence of OCB towards performance. Ekowati, Troena, and Noermijati (2013) also provided research results which shows that OCB directly influences performance and OCB mediates working satisfaction on employees' performance. The research conducted by Lee, Kim, and Kim (2013) shows that transformational leadership had a positive effect on employees' OCB. Also, Luthans and Youssef (2007) research revealed transformational leadership affecting OCB.

The recent tight competition demanded BPR management to always maintain and improve employees' performance in order to guarantee the sustainability of BPR operation. This research gave new model in sustainable performance improvement based on OCB by observing transformational leadership and working satisfaction. Employees' high performance can be achieved if there is harmonious condition on the applied leadership function, therefore, it is capable to improve BPR employees' satisfaction. Further, the employees will be gladly do the given job and in effect, supporting organization's function.

\section{Literature Review}

\section{Performance}

Employees performance basically is the result of employes' work during certain period compared with various possibilities, e.g., standard, target, aims, or other criterias set and agreed previously, therefore performance assessment is different from one company to another (Nimran et. al, 2011: 173). Performance refers to individual working achievement measured based on standard or 
criteria set by an organization (Adolfina, 2014). According to Mathis and Jackson (2002: 81), for performance or work's result of an employer, a set of questions consisted of several dimensions on work's result or performance is used. There are five criterias used to assess employee, i.e., working quantity, working quality, time utilization, presence rate, and cooperation.

\section{Organizational Citizenship Behavior (OCB)}

According to Robbins (2006: 31), OCB is selected behavior which is not part of formal working obligation of an employer, but supports the functioning of an organization effectively. Triyanto and Santosa (2010), stated that OCB is voluntary behavior which is visible and observable. Further, Nimran et. al (2011: 85) stated that there are five primary dimensions of OCB, i.e., altruism, civic virtue, conscientiousness, courtesy, and sportsmanship. The high level of OCB will improve employee's performance because OCB significantly influences employee's performance (Ariani, 2008; Chiang \& Hsieh, 2012; Ekowati et al., 2013).

\section{Transformational Leadership}

Transformational leadership can be defined as a process to transform individual to be willing and improving him/herself, which consisted of motive and needs fulfillment and appreciation towards subordinates (Robbins and Judge, 2008: 91). Artina (2013) stated that transformational leadership in principle motivates the subordinate to be better than what is possible to be done, in other words able to improve the subordinate's trust or confidence which will be influential for performance improvement. Bass and Avolio (1993) stated that transformational leadership has four dimensions called as "the Four I's", i.e., idealized influence, inspirational motivation, intellectual stimulation, and individualized consideration. Gunawan (2016) stated that leadership is one of things that can influence OCB because without effective leadership, a company will experience setbacks. Transformational leadership results in positive effects towards OCB (Luthans \& Youssef, 2007).

\section{Working Satisfaction}

Luthans (2006: 243) stated that working satisfaction is a state of happy or positive emotion generated from working assessment or someone's working experience. Generally, working satisfaction can be understood from three aspects, i.e., working satisfaction is emotional response towards working situation, working satisfaction often determined based on how good the achieved result or exceeding expectation and working satisfaction representing several related behaviors. Coomber and Barriball (2007) stated that working satisfaction is an assessment on how much the employee work in overall to fulfill their needs. Working satisfaction is very closely related with employee's behavior toward his/her own works, working situation, cooperation between leader and employee. According to Robbins (2006: 181), factors that boost working satisfaction is mentally challenging works, appropriate reward, supporting working condition, working partner, and personal suitability with the job. Working satisfaction significantly related with OCB (Magdalena, 2014). Research conducted by Ekowati et al. (2013) stated that working satisfaction significantly influences OCB. Further, Zeinabadi (2010) added that intrinsic working satisfaction is dominant variable directly influencing OCB.

Based on problem formulation, research's purpose, theoretical basis, and previous researchers explained before, the hypotheses in this research are:

a. OCB can mediate transformational leadership towards performance.

b. OCB can mediate working satisfaction towards performance. 


\section{Methods}

This research is explanatory research with survey method. Population in this research is 319 employees of BPR in East Java. Samples are 76 employees taken by simple random sampling. Data source used are primary data and secondary data. Primary data gathered by instrument in the form of questionnaire using Likert scale with range $1-5$ as data measurement. Next research instrument validity and reliability is tested. Further, classic assumption test consisted of normality, heteroscedasticity, and multicollinearity is conducted. Data analysis technique used descriptive analysis and path analysis.

\section{Result and Discussion}

East Java province has $19.88 \%$ conventional BPR from all BPR in Indonesia and it is the highest number among all other provinces. On its progress, BPR need to improve employees' performance in order to be able to offer high quality banking service to the customers and to comply with regulations. The majority of respondents in this research are male, age ranged from 26 to 30 years old, married, bread winner for two people, and their working length is ranged from two to four years.

\section{Validity Testing Result}

The result of validity and reliability test is shown in the following table.

Table 1: Validity Test Result

\begin{tabular}{|c|c|c|c|c|c|}
\hline Variable & & $\begin{array}{l}\text { Indicator } \\
\text { Item }\end{array}$ & r count & $r$ table & Description \\
\hline $\begin{array}{l}\text { Transformational } \\
\text { (X1) }\end{array}$ & Leadership & $\begin{array}{l}\text { X1.1 } \\
\text { X1.2 } \\
\text { X1.3 } \\
\text { X1.4 } \\
\text { X1.5 } \\
\text { X1.6 } \\
\text { X1.7 } \\
\text { X1.8 } \\
\text { X1.9 } \\
\text { X1.10 } \\
\text { X1.11 } \\
\text { X1.12 }\end{array}$ & $\begin{array}{l}.418 \\
.762 \\
.808 \\
.777 \\
.651 \\
.720 \\
.689 \\
.768 \\
.757 \\
.722 \\
.781 \\
.736\end{array}$ & 0.190 & $\begin{array}{l}\text { Valid } \\
\text { Valid } \\
\text { Valid } \\
\text { Valid } \\
\text { Valid } \\
\text { Valid } \\
\text { Valid } \\
\text { Valid } \\
\text { Valid } \\
\text { Valid } \\
\text { Valid } \\
\text { Valid }\end{array}$ \\
\hline
\end{tabular}


Table 1( cont'd): Validity Test Result

\begin{tabular}{|c|c|c|c|c|}
\hline Variable & $\begin{array}{l}\text { Indicator } \\
\text { Item }\end{array}$ & r count & $r$ table & Description \\
\hline \multirow[t]{11}{*}{ Working Satisfaction (X2) } & X2.1 & .448 & \multirow[t]{11}{*}{0.190} & Valid \\
\hline & $\mathrm{X} 2.2$ & .774 & & Valid \\
\hline & $\times 2.3$ & .636 & & Valid \\
\hline & X2.4 & .510 & & Valid \\
\hline & $\times 2.5$ & 612 & & Valid \\
\hline & X2.6 & .557 & & Valid \\
\hline & $\times 2.7$ & .497 & & Valid \\
\hline & $\mathrm{X} 2.8$ & .647 & & Valid \\
\hline & X2.9 & .576 & & Valid \\
\hline & $\times 2.10$ & .679 & & Valid \\
\hline & $\mathrm{X} 2.11$ & .722 & & Valid \\
\hline \multirow[t]{12}{*}{ OCB (Y1) } & Y1.1 & .474 & \multirow[t]{12}{*}{0.190} & Valid \\
\hline & Y1.2 & .553 & & Valid \\
\hline & Y1.3 & .502 & & Valid \\
\hline & Y1.4 & .705 & & Valid \\
\hline & Y1.5 & .683 & & Valid \\
\hline & Y1.6 & .502 & & Valid \\
\hline & Y1.7 & .657 & & Valid \\
\hline & Y1.8 & .731 & & Valid \\
\hline & Y1.9 & .674 & & Valid \\
\hline & Y.10 & .758 & & Valid \\
\hline & Y1.11 & .696 & & Valid \\
\hline & Y1.12 & .691 & & Valid \\
\hline \multirow[t]{11}{*}{ Performance (Y2) } & Y2.1 & .532 & \multirow[t]{11}{*}{0.190} & Valid \\
\hline & Y2.2 & .616 & & Valid \\
\hline & Y2.3 & .622 & & Valid \\
\hline & Y2.4 & .636 & & Valid \\
\hline & Y2.5 & .666 & & Valid \\
\hline & Y2.6 & .659 & & Valid \\
\hline & Y2.7 & .699 & & Valid \\
\hline & Y2.8 & .601 & & Valid \\
\hline & Y2.9 & .615 & & Valid \\
\hline & Y2.10 & 673 & & Valid \\
\hline & Y2.11 & .739 & & Valid \\
\hline
\end{tabular}

Source: processed data, 2017

Table 2: Reliability Test Result

\begin{tabular}{llll}
\hline No & Variable & Cronbach's Alpha & Description \\
\hline 1 & X1 & .772 & \\
2 & X2 & .758 & Reliable \\
3 & Y1 & .761 & Reliable \\
4 & Y2 & .764 & Reliable \\
\hline
\end{tabular}

Source: processed data, 2017 
The above table shows that all research instrument points have fulfilled the validity criteria. The same also applies with research variable, all have fulfilled reliability criteria. Next, classic assumption test is conducted with the result as following:

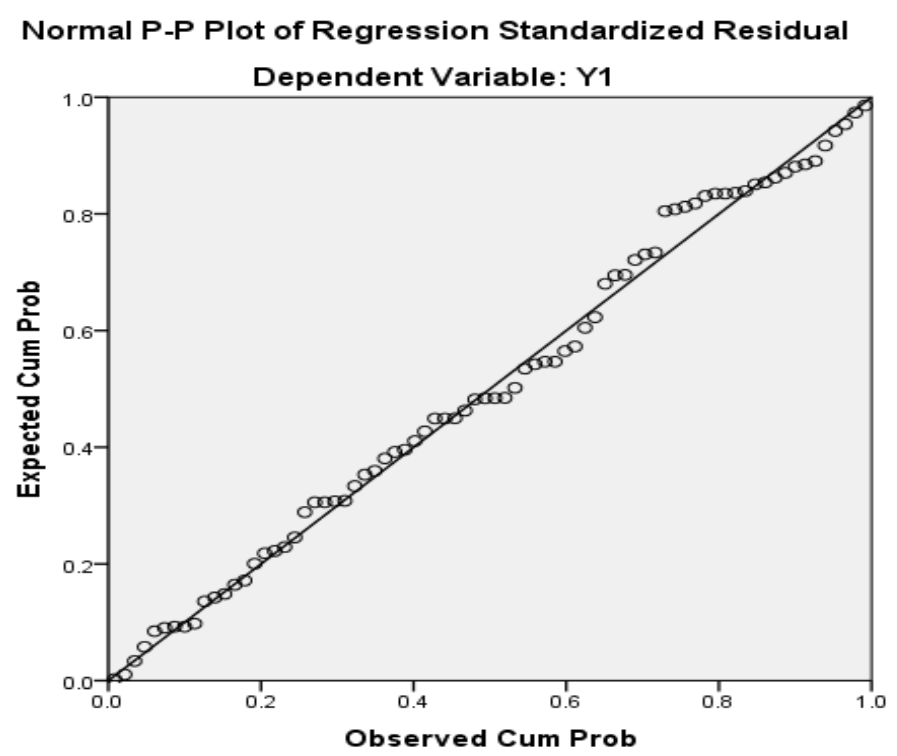

Figure 1: Normal Probability Plot variables X1, X2 and Y1 Graphic

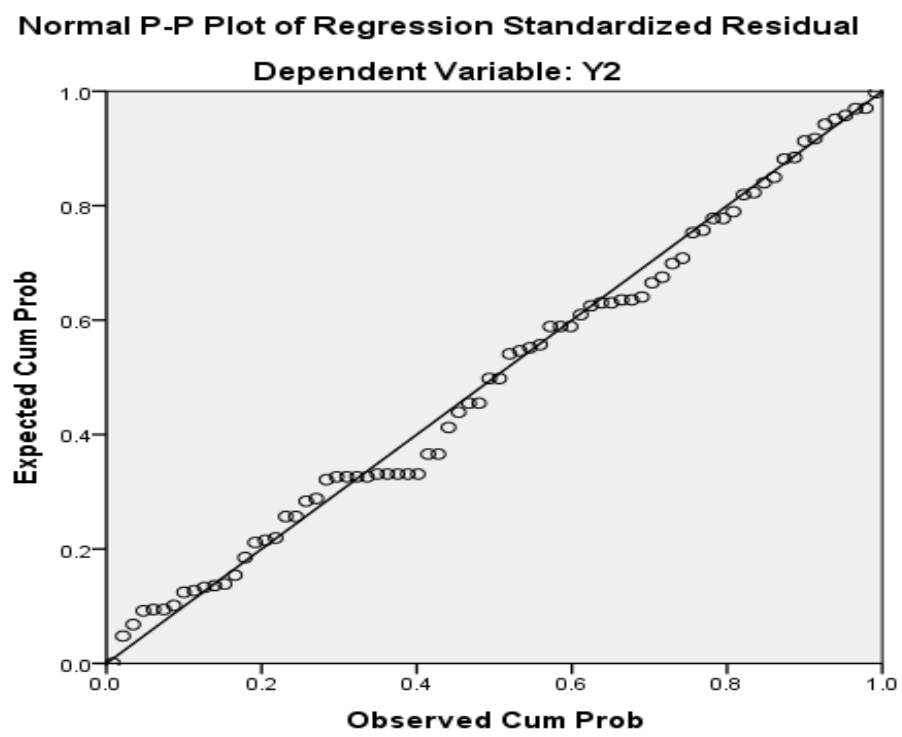

Figure 2: Normal Probability Plot variables Y1 and Y2 Graphic

Present the distributed dots within the diagonal line and its distribution follows the diagonal line. Thus the regression model has met the normality assumption.

Note:

X1: Transformational Leadership

X2: Working Satisfaction 
Y1: OCB (Organizational Citizenship Behavior)

Y2: Perfomance

Table 3: Multicollinearity Test Result

\begin{tabular}{lll}
\hline No & Independent Variable (X) & VIF \\
\hline 1. & Transformational leadership (X1) & 2.342 \\
2. & Working satisfaction (X2) & 2.342 \\
3 & OCB (Y1) & 1.000 \\
\hline
\end{tabular}

Source: processed data, 2017

Multicollinearity test result in Table 3 shows that the variance inflation factor (VIF) values for all exogenous variables are below 10. Thus, means that there is no linear relationship between independent variables in this study. Whereas, the result of heteroscedasticity test for each path of this research variable is as follows:

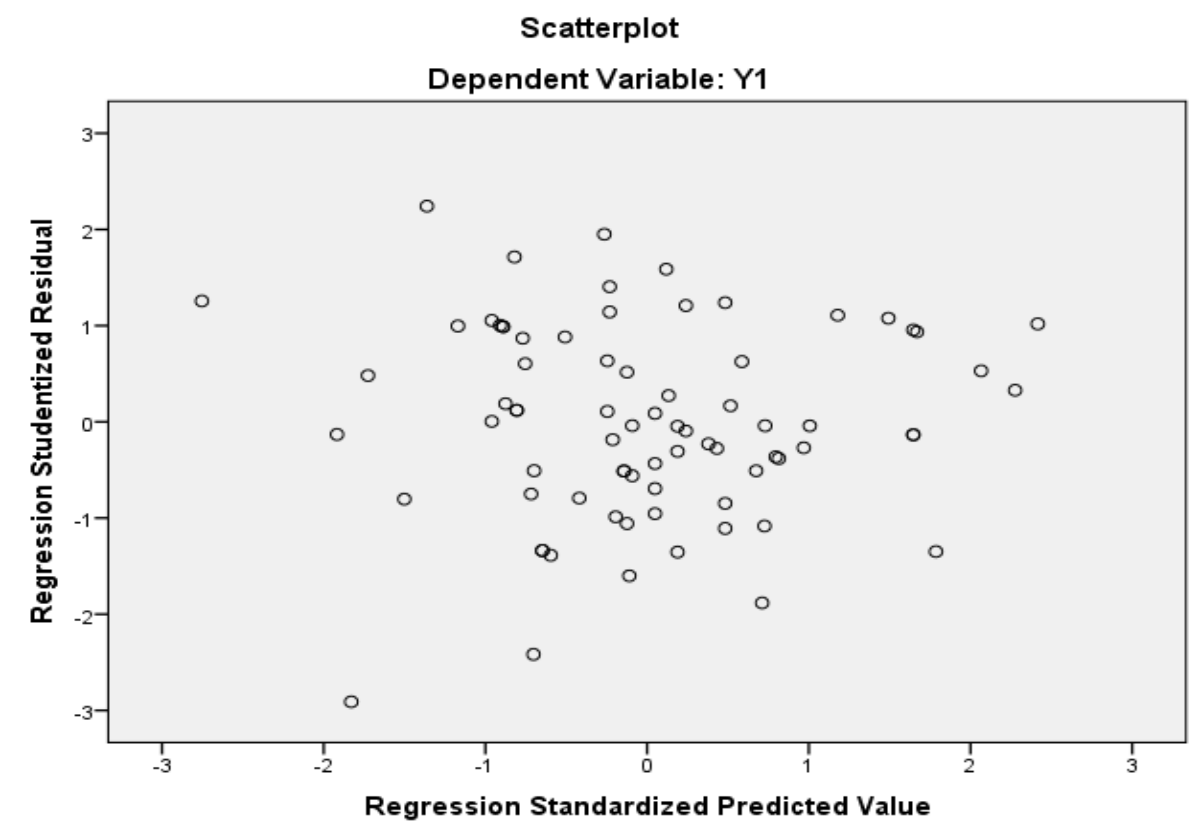

Figure 3: Scatterplot graphs of variables $\mathrm{X} 1, \mathrm{X} 2$ and $\mathrm{Y} 1$ 


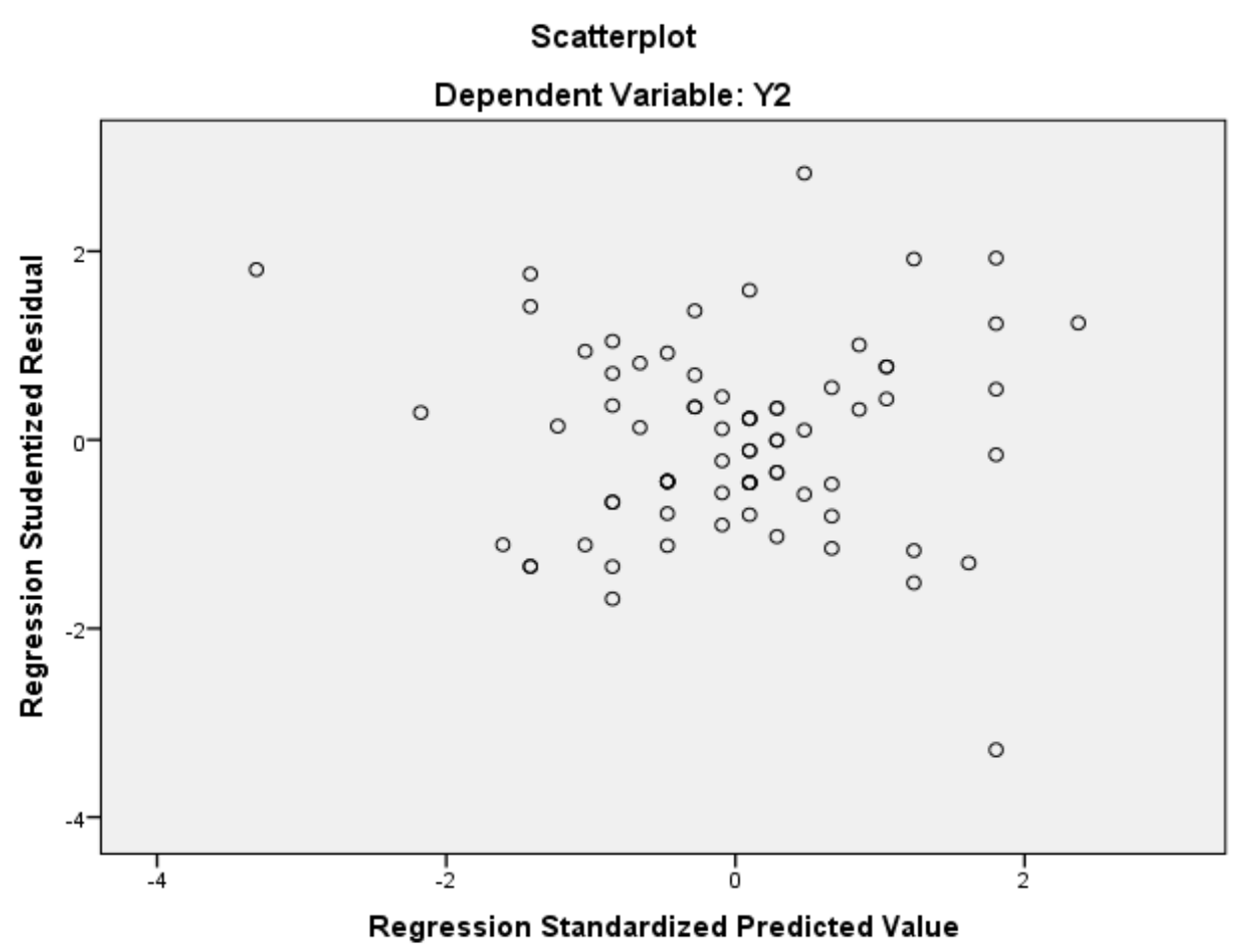

Figure 4: Scatterplot graphs of variables $Y 1$ and $Y 2$

From figure 3 and 4 , it can be seen that the points spread randomly, not forming a certain clear pattern, as well as scattered either above or below the number 0 on the $Y$ axis. This means that in the model there is no heteroscedasticity for the influence between the exogenous variables of transformational leadership, working satisfaction toward OCB as well as OCB variable toward performance of BPR in East Java.

\section{Path Analysis Test Result}

The path analysis test result is decribed in the picture below:

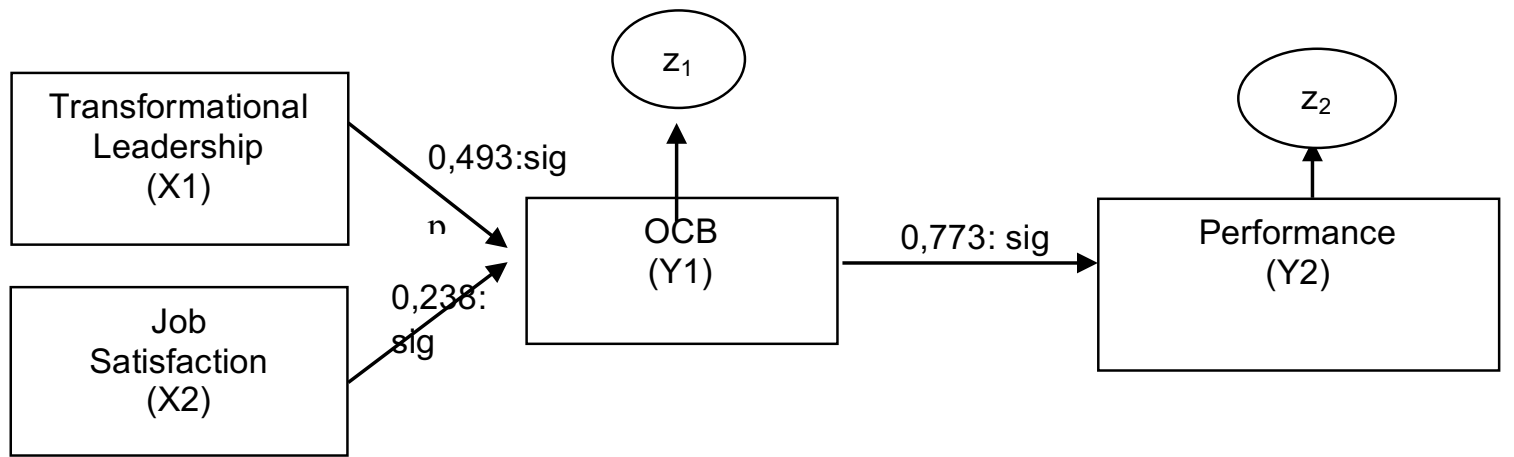

Figure 5: Tranformational Leadership path diagram Working satisfaction, OCB and Performance

The measuring model for showing the relation between variable is decribed below:

Model 1: OCB $=0,493 \times 1+0,238 \times 2$ 
Model 2: Performance $=0.773$ Y2

The partial hypotheses testing used whether to examine and the influence of variable exogenous partially toward endogenous variable, with the result as below:

Table 4: Partial Hypotheses Testing Result

\begin{tabular}{lllll}
\hline No & Exogenous Variable & $\begin{array}{l}\text { Endogenous } \\
\text { Variable }\end{array}$ & $\begin{array}{l}\text { Path } \\
\text { Coef. }\end{array}$ & Prob. \\
\hline 1 & Transformational Leadership & OCB & 0,493 & .000 \\
2 & Working satisfaction & & 0,238 & .070 \\
3 & OCB & Performance & 0,773 & .000 \\
\hline
\end{tabular}

Source: processed in 2017

The influence testing on transformational leadership to OCB resulting on 0.00 value of probability, meaning there is a direct significant influence to transformational leadership to OCB. The working satisfaction influence to OCB result to the value of probability in the amount of 0.070 means that there is a direct influence to working satisfaction in OCB. The influence testing of OCB to performance result to the probability value in the amount of 0.00 , representing significant direct influence of $O C B$ to performance. The result of transformational leadership to the performance through OCB shows indirect influence of transformational leadership to performance trough OCB. The influence testing result to performance trough OCB known that there is indirect influence of working satisfaction to performance through OCB.

Assessment of Goodness of fit Model used to analyze the diversity of exogenous variables or to investigate the contribution of exogenous variables to endogenous variables. Goodness of fit Model in path analysis is done by using Coefficient of Total Determination $\left(R^{2}{ }_{m}\right)$. The results of the assessment of Goodness of fit Model in this research has been summarized in the following table:

Table 5: Goodness of Fit Model Test Result

\begin{tabular}{ll}
\hline Variables & $\boldsymbol{R}^{\mathbf{2}}$ \\
\hline OCB & 0.478 \\
Employee Performance & 0.598 \\
$\mathrm{R}_{\mathrm{m}}^{2}=1-\left(\left(1-\mathrm{R}^{2}{ }_{\text {OCB }}\right) *\left(1-\mathrm{R}^{2}{ }_{\text {Performance }}\right)\right)$ & \\
$\mathrm{R}_{\mathrm{m}}^{2}=1-((1-0478) *(1-0,598))=0,790$ & \\
\hline
\end{tabular}

Source : Processed data, 2017

R-square of OCB variable is 0,478 or $47,8 \%$. This shows that the diversity of OCB is explained by transformational leadership and working satisfaction by $47.8 \%$, or in other words the contribution of transformational leadership and working satisfaction to OCB is $47.8 \%$, while the rest of $52.2 \%$ is the contribution of other variables not discussed in this study.

R-square performance variable is 0.598 or $59.8 \%$. This shows that the diversity of performance can be explained by OCB employees by $59.8 \%$, or in other words the contribution of employees 
OCB to the performance is $59.8 \%$, while the remaining $40.2 \%$ is another variable contribution not discussed in this study.

Total Determination of Coefficient $\left(\mathrm{R}_{\mathrm{m}}^{2}\right)$ is worth 0.790 or $79 \%$. This shows that the diversity of performance can be explained by the overall model by $79 \%$. In other words as a whole, transformational leadership, working satisfaction and OCB play part by $79 \%$ of total performance quality, while the remaining $21 \%$ is the contribution of other variables that are not discussed in research this.

There is indirect influence in the path analysis, the indirect influence and total influence. The direct and indirect influence can be served in the table below:

Table 6: Direct influence, Indirect influence, and Total influence

\begin{tabular}{llllll}
\hline Exogenous & Mediation & Endogenous & Direct & Indirect & Total \\
\hline $\begin{array}{l}\text { Transformational } \\
\text { Leadership }\end{array}$ & OCB & 0,493 & & 0,493 \\
Working Satisfaction & & OCB & 0,238 & & 0,238 \\
OCB & & Performance & 0,773 & & 0,773 \\
$\begin{array}{l}\text { Transformational } \\
\text { Leadership }\end{array}$ & OCB & Performance & & $0,493 \times 0,773$ & 0,849 \\
Working Satisfaction & OCB & Performance & & $0,238 \times 0,773$ & 0,329 \\
\hline
\end{tabular}

Source: Processed data, 2017

Direct influence coefficient of transformational leadership on OCB is 0.493 . Transformational leadership has positive influence on $\mathrm{OCB}$, which by increasing the quality of transformational leadership, the OCB would also improve. Direct influence coefficient of working satisfaction on $O C B$ is 0.238 . Working satisfaction has positive influence on $O C B$, which by feeling satisfactory of their working, the staffs would engage more on OCB. Direct influence coefficient of OCB on performance is 0.773 . OCB has positive influence on performance, which by the more intensity of OCB is occurred, the better staff's performance would be. Indirect influence coefficient of transformational leadership, mediated by OCB, on performance is 0.849 . Transformational leadership, mediated through $\mathrm{OCB}$, has positive influence on performance. When OCB is increased by better quality of transformational leadership, staff's performance level would also increase. Indirect influence coefficient of working satisfaction, mediated by OCB, on performance is 0.329 . When OCB is increased by higher working satisfaction, staff's performance level would also increase.

The most influential exogenous variable is one with the highest coefficient on the endogenous variable. Transformational leadership has stronger influence coefficient than working satisfaction, even after mediated by OCB. Hence, transformational leadership, mediated by OCB, has dominant influence on performance

\section{Discussion}

The leader is exposed to be able to change the behavior of its staff to be better. The transformational leadership encourage the staff to be more innovative and creative in performing the task by giving the trust to the staff for improving the self and the organizational system, thus, 


\section{S. Harnani / International Journal of Research in Business and Social Science, Vol 6 No 5, Special Issue 2017 ISSN: 2147-4486}

the OCB behavior is appeared. OCB is a staff's behavior choice which involves BPR that encourage them to work beyond what is tasked to support the effective function of the organization (Robbins, 2006: 31). The research result shows direct transformational leadership influence to OCB. This means that the practice of leadership concept that has transformational style in the East Java BPR is able to give effect to OCB's staff. This is in line to Luthan's (2006: 654 ) who believes that transformational leadership has OCB result. This is also supported by research result done by Cho and Dansereau (2010) who found relation between transformational leadership and OCB. The research result from Gunawan (2016) also explained a strong positive relation between transformational leadership with OCB.

The practice of transformational leadership results to the influence of OCB behavior to staff the influence to performance. This research result shows that OCB is able to being the mediation for transformational leadership and performance. This means the practice of transformational leadership in East Java BPR is able to give indirect impacts on to performance influence through OCB. The working satisfaction is an emotional expression felt by each individual for working comprehensively. The form of working satisfaction can be seen from working enjoyment and the staff's experience of hope and reality, because the staff working in pleasure will produce OCB behavior. This research result show that working satisfaction has significant effect to OCB. This is in line with the research done by Ekowati et al. (2013) who stated that working satisfaction gives significant influence to OCB and so does the research done by Zeinabadi (2010) who stated that working satisfaction has direct influence to OCB. Rohayati (2014) found that there is significant influence between working satisfaction to staffs' OCB. Then, Rahman (2014) also found that working satisfaction has influence on OCB.

The working satisfaction felt by the staff can also be seen from loyalty behavior in the organization besides of their responsibility and counted in the rewarding system. The working satisfaction effect on OCB behavior of staff by then will influence the performance. The result of this research shows that $O C B$ is able to mediate the working satisfaction to performance. It means that the working satisfaction is felt by the BPR staff of East Java is able to give indirect impact to performance improvement through $O C B$, this supports the research done by Ekowati et al. (2013) which also found OCB's role mediating working satisfaction for performance.

\section{Conclusion}

The result of this research shows that OCB is able to mediate the influence of transformational leadership for performance in East Java BPR. OCB is also able to mediate the influence of working satisfaction for BPR East Java's performance.

\section{Acknowledgement}

This research has been granted funding from Directorate General of Research and Development Enhancement, Ministry of Research, Technology, and Higher Education of the Republic of Indonesia (No. SP DIPA-042.06.1.4051516/2017 on December, $7^{\text {th }} 2016$ ). Author would like to express gratitude for Region VII Kopertis of East Java, without whom this research wouldn't be possible. 


\section{References}

Adolfina, A. (2014). Analisis Keterkaitan Antara Kepuasan Kerja, Dan Komitmen Organisasi Dengan Kinerja Individu. Jurnal Riset Ekonomi, Manajemen, Blisnis Dan Akuntansi, 2(3). Retrieved from https://ejournal.unsrat.ac.id/index.php/emba/article/view/5724

Ariani, D Wahyu. 2008. The Relationship Between Task Performance and Contextual Performance with Job Satisfaction, Commitment and Personality. Journal of Performance. Vol. 1, No. 2 : $165-181$.

Artina, Nyimas. 2013. Analisis Pengaruh Kepemimpinan Transformasional, Motivasi Kerja Dan Pengembangan Karir Terhadap Kinerja Karyawan PT. Multi Data Palembang Information Technology Super Store. Forum Bisnis Dan Kewirausahaan. Jurnal IImiah STIE MDP, Vol. 3 No. 1 September 2013 Hal - 53

Bass, B. M., \& Avolio, B. J. (1993). Transformational Leadership And Organizational Culture. Public Administration Quarterly. SPAEF. https://doi.org/10.2307/40862298

Chiang, C.-F., \& Hsieh, T.-S. (2012). The impacts of perceived organizational support and psychological empowerment on job performance: The mediating effects of organizational citizenship behavior. International Journal of Hospitality Management, 31(1), 180-190. https://doi.org/10.1016/j.jijhm.2011.04.011

Cho, J., \& Dansereau, F. (2010). Are transformational leaders fair? A multi-level study of transformational leadership, justice perceptions, and organizational citizenship behaviors. The Leadership Quarterly, 21(3), 409-421. https://doi.org/10.1016/J.LEAQUA.2010.03.006

Coomber, B., \& Barriball, K. L. (2007). Impact of job satisfaction components on intent to leave and turnover for hospital-based nurses: A review of the research literature. International Journal of Nursing Studies, 44(2), 297-314. https://doi.org/10.1016/J.IJNURSTU.2006.02.004

Ekowati, V. M., Troena, E. A., \& Noermijati, N. (2013). Organizational Citizenship Behavior Role in Mediating the Effect of Transformational Leadership, Job Satisfaction on Employee Performance: Studies in PT Bank Syariah Mandiri Malang East Java. International Journal of Business and Management, 8(17), 1. https://doi.org/10.5539/ijbm.v8n17p1

Gunawan, R. (2016). Pengaruh Kepemimpinan Transformasional Terhadap Organizational Citizenship Behavior (OCB) Pada PT First Marchinery Tradeco Cabang Surabaya. AGORA, 4(1). Retrieved from https://media.neliti.com/media/publications/36504-IDpengaruh-kepemimpinan-transformasional-terhadap-organizational-citizenshipbehav.pdf

Lee, U. H., Kim, H. K., \& Kim, Y. H. (2013). Determinants of Organizational Citizenship Behavior and Its Outcomes. An International Journal, 5(1). Retrieved from https://search.proquest.com/openview/d21cb75f8554a8b7777d8e0b990d13bc/1?pqorigsite $=$ gscholar $\& \mathrm{cbl}=696409$

Luthans, Fred S., 2006. Organizational Behavior. New York : McGraw-Hill.

Luthans, F., \& Youssef, C. M. (2007). Emerging Positive Organizational Behavior. Journal of Management, 33(3), 321-349. https://doi.org/10.1177/0149206307300814 
Lyons, B. J., \& Schneider, T. R. (2005). The influence of Emotional Intelligence on Performance. $\begin{array}{llll}\text { Personality and Individual } \quad \text { Differences, } & \text { 39(4), }\end{array}$ https://doi.org/10.1016/J.PAID.2005.02.018

Magdalena, S. M. (2014). The Effects of organizational Citizenship Behavior in the Academic Environment. Procedia - Social and Behavioral Sciences, 127, 738-742. https://doi.org/10.1016/J.SBSPRO.2014.03.346

Mathis, Robert L. dan Jhon H. Jackson. 2002. Manajemen Sumberdaya Manusia. Edisi Pertama, Cetakan Pertama, Jakarta : Salemba Empat.

Nimran, Umar dan Amirullah, 2011, Manajemen Sumber Daya Manusia \& Perilaku Organisasi, Malang : Sinar Akademika

Njotoprajitno, R. S. (2012). Pengembangan Dan Pemberdayaan Bpr Dalam Upaya Peningkatan Usaha Kecil Dan Menengah Di Indonesia - Universitas Stikubank (Unisbank) Semarang Repository. Retrieved September 27, 2017, from http://eprints.unisbank.ac.id/195/

Rahman, U. (2014). Kepuasan Kerja Dan Organizational Citizenship Behavior Pada Guru Madrasah Aliyah Madani Alauddin Paopao Gowa Sulawesi Selatan. Analisa, 21(1), $131-$ 142. Retrieved from https://media.neliti.com/media/publications/41976-ID-kepuasankerja-dan-organizational-citizenship-behavior-pada-guru-madrasah-aliyah.pdf

Robbins, S. 2006. Perilaku Organisasi: Konsep, Kontroversi, Aplikasi. Edisi Bahasa Indonesia. PT. Prenhallindo, Jakarta.

Rohayati, A. (2014). Pengaruh Kepuasan Kerja Terhadap Organizational Citizenship Behavior: Studi Pada Yayasan Masyarakat Madani Indonesia. SMART - Study \& Management Research, 11(1), 20-35. Retrieved from http://stiestembi.ac.id/file/3. Ai Rohayati _SMART, Vol XI, No. 1 - 2014.pdf

Siamat, Dahlan, 2005, Manajemen Lembaga Keuanngan, Kebijakan Moneter dan Perbankan, Edisi kelima, Jakaarta : Lembaga Penerbit Fakultas Ekonomi Universitas Indonesia.

Triyanto, A., \& Santosa, T. E. C. (2010). Organizational Citizenship Behavior (OCB) dan Pengaruhnya Terhadap Keinginan Keluar dan Kepuasan Kerja Karyawan. Jurnal Manajemen Maranatha, 8(2), 52-65. Retrieved from http://majour.maranatha.edu/index.php/jurnal-manajemen/article/view/219

Zeinabadi, H. (2010). Job satisfaction and organizational commitment as antecedents of Organizational Citizenship Behavior (OCB) of teachers. Procedia - Social and Behavioral Sciences, 5, 998-1003. https://doi.org/10.1016/J.SBSPRO.2010.07.225 , 2017. Perhimpunan Bank perkreditan Rakyat (PERBARINDO) Jawa Timur. , malangvoice,com, diakses pada 2 November 2016. 